Sustinere

Journal of Environment and Sustainability

Volume 3 Issue 2 (2019) 75-89

Print ISSN: 2549-1245 Online ISSN: 2549-1253

Website: https://sustinerejes.com E-mail: sustinere.jes@iain-surakarta.ac.id

\title{
RESEARCH PAPER \\ Earthquakes in Javanese theological interpretation: The study of Serat Primbon manuscripts from the Yogyakarta Sultanate Palace
}

\author{
Islah Gusmian* \\ Faculty of Ushuluddin and Da'wah, Institut Agama Islam Negeri Surakarta, Indonesia \\ Article history: \\ Received 7 July 2019 | Accepted 22 August 2019| Available online 31 August 2019
}

\begin{abstract}
This article examined the Javanese view on the earthquakes recorded in the manuscripts. Javanese people were chosen because they have a typical and unique view in interacting with fellow humans, nature and God. While the manuscripts were placed as a database, because it is a historical record, thoughts, attitudes, views in the past. There are three problems examined in this article, namely: how are the understanding and attitudes of the Javanese people towards earthquake events, what are the factors influencing that understanding, and what are the functions in disaster mitigation? By using Karl Mannheim's sociological theory of knowledge, it was found that Javanese people understand earthquakes as a sign system attached to predictive and subjective-imaginative meanings and spiritually responded to by prayer and slametan ceremonies. And the most important thing found in this study is that the Javanese understand the earthquakes actively and positively, in which they always move from one destiny to another to maintain harmony and safety.
\end{abstract}

Keywords: Java manuscript; earthquake; Javanese culture; Yogyakarta Sultanate Palace

\section{Introduction}

Indonesia is one of the regions frequently hit by earthquakes with a variety of consequences. This happens because Indonesia has many active volcanoes and is geologically situated at the confluence of three major tectonic plates of the world, namely the Eurasian Plate, the Indo-Australian Plate and the Pacific Plate. Earthquake and active volcanic events have resulted in various disasters, such as tsunamis (Gusman et al., 2009; Natawidjaja et al., 2006), earthquake-triggered landslides (Keefer, 2002; Yamada et al., 2013), damage to buildings (Kerle, 2010), damage to bridges and infrastructure (Saatcioglu et al., 2006), triggering volcanic eruption (Manga et al., 2009; Voight et al., 2000), and liquefaction (Mase, 2019), which endangered human lives. During the period of 1600-1999, there were 105 tsunamis in Indonesia where 90 percent of which were caused by earthquakes (Latief et al., 2000). Specifically in Java, from 1797 to 2006 there were at least 25 earthquake events (Elnashai et al., 2007). On the basis

${ }^{*}$ Corresponding author. E-mail: islahgusmian@gmail.com

DOI 10.22515/sustinere.jes.v3i2.79 
of such geological conditions, from time to time, residents in Indonesia have faced various earthquake events and a variety of consequences.

Noted, since hundreds of years ago, Indonesia experienced earthquakes. There are recordings of 3650 earthquakes that occurred in Sumatra to Andaman in the period of 1918 2005 (Engdahl et al., 2007). But previously, records of large earthquakes with magnitudes of more than 8 ritcher scales in Indonesia have been recorded since the 1700s, for example an earthquake in Padang that occurred in 1797 (Natawidjaja et al., 2006), in Mentawai in 1833 (Natawidjaja et al., 2006), and in Nias in 1861 (Engdahl et al., 2007; Mccloskey et al., 2008). Figure 1 shows a part of the history of earthquakes that occurred in Indonesia from 1900 to 2012.

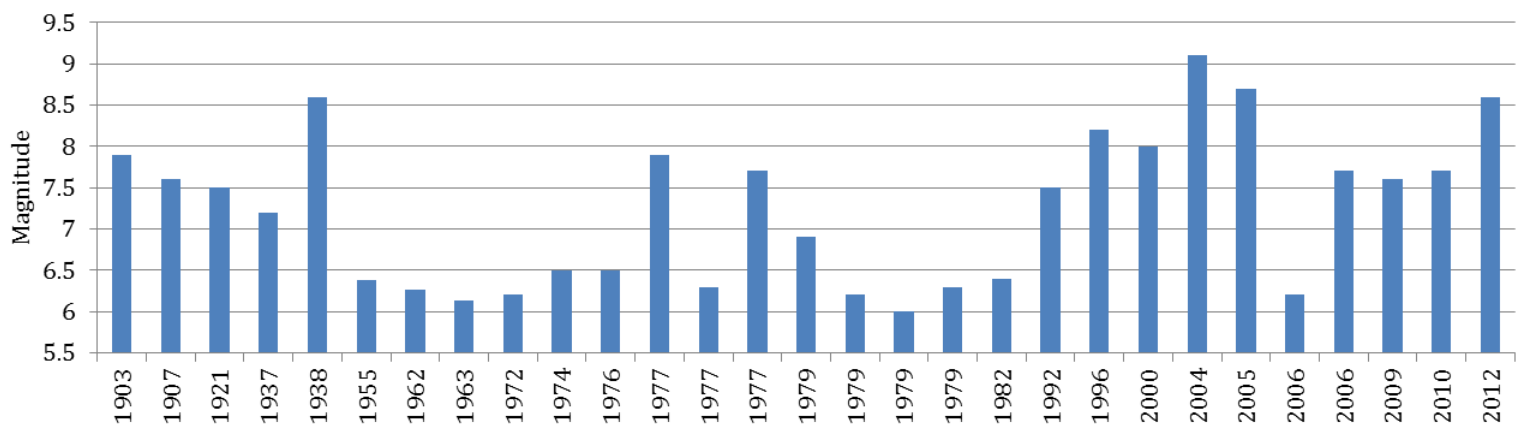

Figure 1. Some earthquakes in Indonesia since 1900 - 2012. References: in Java in 1903, 11 September 1921, 27 September 1937, 21 December 1955, 16 December 1962, 28 May 1963, 7 September 1972, 14 July 1974, 1977, 1979 and 1982 (Elnashai et al., 2007), Simeulue on 27 February 1907 (Mccloskey et al., 2008), Banda Sea earthquake on 1 February 1938 (Okal \& Reymond, 2003), 19 August 1977 (Nakamura, 1979; Stein \& Nunn, 1981). Flores on 12 December 1992 (Hidayat et al., 1995), Biak on 17 February 1996 (Hayakawa et al., 2000; Henry \& Das, 2002), South Sumatra earthquake on 4 July 2000 (Zhou et al., 2002), Aceh earthquake on 26 December 2004 (Banerjee et al., 2007; Rosenzweig et al., 2006). Nias earthquake on 28 March 2005 (Natawidjaja et al., 2006; Rosenzweig et al., 2006), Jogjakarta earthquake on 27 May 2006 (Tsuji et al., 2009), Padang on 30 September 2009 (Mccloskey et al., 2010), Mentawai earthquake on 25 October 2010 (Ardika et al., 2015; Satake et al., 2012). North Sumatera earthquake on 11 April 2012 (Wang et al., 2012).

The long and repeated experiences experienced by the Indonesian people, socially and culturally, ultimately shape certain attitudes and ways of thinking in facing and understanding earthquake events. The attitudes and ways of thinking that grow and have been formed are important to be explored to find the core of the attitudes and views of the Indonesian people in the past in facing earthquake events. The aim is to make the people of Indonesia do not lose their wisdom in the past and can even use it as a means of disaster mitigation. This kind of exploration is important because even though the earthquakes and various disasters caused do not occur at the same time, the things and situations experienced by the affected people, both material and immaterial, are essentially the same. 
This article will explore the theological attitudes and views of the Javanese community in the past in facing earthquake events, through manuscripts inherited from the ancestors. Javanese community and manuscripts are the two important things chosen in this study according to two considerations. First, the Java region was chosen as the locus of study because, geologically, it is one of the regions in Indonesia which was hit by many earthquakes. Java is a region that has many mountains. In the southern part of the Java region, there are the North Karst Mountain Range (Situmorang et al., 1992) and the Kendeng Mountain Range which stretch across several regions in Central Java and East Java. The karst mountain range stretches from the east of Semarang to the Lamongan region. The main chains of mountain range in Java are the North Serayu and South Serayu Mountain Range. The North Serayu Mountain Range forms a mountain range connecting the Bogor range in West Java with the Kendeng Mountain Range in the east. The width of this mountain range is around $30-50 \mathrm{~km}$. At the western end there is Mount Slamet and in the east is the Dieng Plateau with its peak named Mount Prahu and Mount Ungaran. The North Serayu Mountain range and South Serayu Mountain Range are separated by the Serayu Depression which stretches from Majenang, Purwokerto, to Wonosobo. In the east of this depression there are volcanoes, namely Mount Sindoro and Mount Sumbing, and in the east of it, there are the Temanggung and Magelang regions, which are the continuation of the depression bordering Mount Merapi and Mount Merbabu (Situmorang et al., 1992). In the past, as an agrarian and mountainous area, the population in Java mostly worked as farmers. With such conditions, in living everyday life, Javanese people had a view of life about the importance of harmonious relations between humans, humans with God, and with nature. The attitudes and views of the Javanese community cannot be separated from these three aspects. This view was depicted in the concept of container or wadhah and content or isi, as well as the balance and irregularity of the elements contained in it (Purbatjaraka, 1985).

Second, the manuscript was chosen, because it is a cultural product of the past. It contains a variety of knowledge, history, attitudes, and wisdom that lives in society. From a cultural standpoint, it is also a representation of a culture and history when the manuscript was written. Thus, indirectly, the manuscript is one source of knowledge about the attitudes and views of Indonesian society in the past. These attitudes and views can be contextualized to understand natural, social and cultural events in the present. In reading texts from the past, we may only get one event, but the lessons and values in it can be reconstructed and contextualized in the present.

In this article, manuscript representations born from Javanese society were referred to the Serat Primbon manuscript, the collection of Yogyakarta Sultanate Palace, number D6/M269/Bh 139 written by Sri Sultan Hamengkubuwono V (1820-1855 AD). Serat Primbon was chosen because it contains discussion about the earthquake events and reflects the attitudes and views of the rulers in Java who lived in the $19^{\text {th }}$ century AD

By looking at the two main aspects above, this article will explore three main issues as the core of the study. First, how is the theological view of the Javanese society in the past towards the earthquake events which were recorded in the Serat Primbon manuscript, the collection of Yogyakarta Sultanate Palace? Second, what are the factors influencing the formation of the theological views? And third, what is the function of these views in disaster mitigation strategies? 


\section{Various studies on earthquakes in the archipelago}

The study of natural disasters in Indonesia in general has been carried out by a number of researchers with various perspectives. Studies in the fields of science and technology have been commonly carried out by researchers abroad and domestically. However, from the social aspect, especially from manuscript studies, it is still rarely done.

The Religious and Cross-Cultural Studies Program at Gajah Mada University in Yogyakarta has conducted a series of studies related to natural disasters with social, cultural and religious perspectives (Indiyanto \& Kuswanjono, 2012a, 2012b, 2012c). However, the study in general has not explored the social awareness systems, attitudes, and theological views of the Javanese people which are referred to sources that originate from manuscripts.

A study on earthquakes that refers to manuscript data has been done by Hermansyah (2012). The focus of the study is the manuscripts in Aceh. The manuscripts referenced are quite diverse and come from various storage facilities, such as the Aceh State Museum, the collection of Ali Hasjmy Education Foundation, the National Library collection, and a number of private collections. The main thing Hermansyah discovered was about the Acehnese people's records concerning earthquakes that contain goodness and meanness. However, Hermansyah's study did not reveal the theological attitudes and views of the Acehnese people in understanding the earthquake they were facing. At the same time, the manuscripts studied were limited to existing manuscripts and those written by ulemas and the people of Aceh.

Research focusing on the Javanese locus was conducted by Awang Harun Satyana. Awang studied the geological disasters that have occurred in the Java region by referring to the Gununglumpur eruption hypothesis, records in the Pararaton book, Serat Kanda, and Babad Tanah Jawi (Satyana, 2007). The focus of Awang's study is on the geological aspect, not the belief or theological aspects. Therefore, we cannot find the theological attitudes and theological views of the Javanese in this study.

\section{Theoretical Framework and Research Methods}

A study conducted by T.R. Lee regarding the view of a community on certain events becomes important information, in which communities accepting various natural disasters and the consequences gracefully are more active in decision making (Paradise, 2005). This acceptance is built by the perception of each individual, and that perception has an important role in the act of acceptance. For example, people perceiving earthquake events as God's punishment, of course the consequences arising from this perception socially, culturally, and psychologically will be different from the perception that sees earthquake events as God's will and commandments that have been arranged in the framework of natural law. If perception has a role and consequence on the context of the formation of attitudes in dealing with natural disasters, understanding or beliefs originating from attitudes and views that live in a community will have more role and consequence (Drewes \& Mojau, 2006; Ferguson et al., 1988).

In this study, several steps were taken. First, the approach used in this study is the philological approach, which is placing the text of the past, contained in the manuscript, in the context of social and cultural history and connecting the contents of the text with its historical social space. Here, the manuscript was technically explained from two aspects, namely the 
content aspect using textological analysis and physical aspects using codicological analysis (see Lubis, 2007).

The sections examined from this manuscript were textologically focused only on themes related to this study, which are sections describing earthquake events. The intended texts were diverted from the Carakan script to the Latin script then translated and edited, so that they became accurate data. The data was arranged systematically based on the date or calendar, making it easier to make categorization and find relationships between data in the Serat Primbon manuscript.

Secondly, since the Javanese people's theological attitudes and views, which existed in the past, were the ones analyzed in this study, the sociological analysis of knowledge by Karl Mannheim was used. The theory of the sociology of knowledge emphasizes the existence of the subject as one of the elements influencing the practice of understanding. Knowledge and existence are understood as two inseparable things (Mannheim, 1949; Ritzer, 2012; Ritzer \& Goodman, 2004). Knowledge arises and is formed, influenced by the existence of the subject. A knowledge born cannot be separated from the social context of the community that underlies the emergence of that knowledge (Ritzer, 2012). Here, Mannheim linked the idea of a group to the position of the group in the social structure. The decision taken or knowledge possessed is strongly related to the environmental conditions in which they live (Ritzer \& Goodman, 2004). When Mannheim linked knowledge with the social context of society, he made the sociology of knowledge as a sociological-historical theory.

\section{Results}

\subsection{The History of Serat Primbon Manuscript and Divination Reasoning}

Serat Primbon Manuscript from Yogyakarta Sultanate Palace number D6/M269/ Bh 139 by Sri Sultan Hamengkubuwono V (1820-1855 AD) was written using Javanese and Carakan scripts. It consists of 94 pages. Each page contains 20 lines. The text was written in prose. Referring to the date stated in the text, which refers to the first page of the manuscript, the writing began on Tuesday Kliwon, at 12:00, 24th of Muharram in Dal $1775 \mathrm{~J}$ (Javanese calendar), with the tata sabda wiku jalma' chronogram, in Wuku Julungwangi, the sixth season of Lambang Langkir. It coincided with 12 January 1847. The writing finished on Tuesday Kliwon, at 11:00, on 29 Safar in Dal 1775 J, Wuku Mandhasiya, Lambang Langkir, the seventh season with the panca wiku pandhitengrat chronogram, coincided with 27 February 1847 AD. So, this manuscript was written for 46 days.

This Serat Primbon contains many topics. In general, these topics can be divided into four categories, namely the topics of divination or characterization, chronogram, history, prayers and medication. First, in the divination section, there are various discussions, namely the divinations based on the calculation of days, time, astrology, eclipse, human activity, change of seasons, naga sasi or month, and pasaran days. In this section, earthquake events were presented as one part of the topic discussed. Secondly, it is about chronogram. Chronogram or sengkalan or candrasengkala. It originated from saka+kala+an words and then pronounced as sangkalan, then fused into sengkalan. Saka means 'the name of the nation', while kala means 'time'. Sengkalan or chronogram is the writing of the year of events (titi mangsa) and it is read in a reversed way. 
Here, various kinds of chronogram were mentioned, such as chronograms relating to the establishment and collapse of an empire, birth, death, and ascending the throne of a king, and the development or construction of palaces. Third, it is about history. Some of the stories and genealogies presented here, for example, are the history of kings from Prophet Adam to Sri Sultan Hamengkubowo III; the history of the ancestors of Prophet Muhammad up to Prophet Adam; the history of the descendants of Prophet Muhammad SAW until Raden Muhammad Santri in Surabaya, namely Sunan Ampel, Raden Patah's grandfather. Fourth, it is about the treatment or medication techniques that are referred to and harmonized with the patient's neptu and using ingredients from plants.

Matters relating to earthquake events, in this Serat Primbon were narrated in the framework of divination. Earthquakes were understood as a sign system of events that are predicted to occur and be experienced by humans after an earthquake. The divination system was placed on a time frame. In each time, the predictive meaning was placed, the slametan ceremony or ritual and accompanied by prayer. Consider the following quote taken from the section on earthquakes in the Serat Primbon.

Punika ngalamat lindhu, kang awon lan kang sae. Lamun lindu ing sasi Sura, ing rahina, ngalamat akéh wong prihatin. Lamun ing wêngi ngalamat pahilan, beras pari larang, barikane sêga wuduk, dongane slamêt. Lamun lindu ing sasi Sapar, ing rahina, ngalamat akeh wong ngalih-alih. Barikane sega wuduk, dongane qunut, pitik tulak lawuhe. (V 1847, 59)

(The following is the signs of an earthquake, the bad ones and the good ones. If an earthquake occurs in the month of Sura, during the day, it is a sign that many people are concerned. If it (an earthquake) occurs at night, it is a sign [of people becoming] bankrupt, rice or paddy is expensive. The slametan ceremony is uduk rice, the prayer is [begging for] safety, if there is an earthquake in Safar [month], during the day, it is a sign that many people are doing an exodus (from their hometown).

The quotation above shows that earthquake in Serat Primbon is positioned as a sign system in which predictive meanings are attached. Between signs and meanings arranged, it does not have relations that are rational or logical, but the relations are subjective, imaginative and associative. Similar to the interpretation of dreams, between the contents of dreams with the interpretation given tends to be subjective and associative by considering the signs that are in it.

Associated with the attachment of those meanings, as seen in the quote above, there are three main aspects that were built. First, understanding on earthquake events was divided by the time frame, namely day or night and the Javanese months. Second, the meanings given by considering the time frame, and those meanings contain positive and or negative values for human life. In the aspect of time, earthquake events were mapped into three time frame categories, namely day, night, and month. The time category was not referred to the prayer time categories. This is different from the $t a^{\prime} b i r$ text of earthquake originating from Aceh and Padang, in which time categorization in manuscripts originating from these two places was based on the prayer time categories, namely dawn or subuh, dhuha, noon, zuhur, asr, maghrib, isya', and night (Hermansyah, 2012). For example, the manuscript collection of the Aceh State Museum numbered inv. 07,824; inv. 07.523, manuscript collection of Ali Hasjmy Educational Foundation, 
number: 29C/ll/10/YPAH/2005; manuscript collection of the Republic of Indonesia's National Library, in the bundle number ML.464.

Table 1. The narratives of earthquake prophecies in Serat Primbon manuscript

\begin{tabular}{|c|c|c|c|c|}
\hline Month & Time & Divination & $\begin{array}{l}\text { Selamatan } \\
\text { Ceremony }\end{array}$ & Prayers \\
\hline Sura & $\begin{array}{l}\text { Day } \\
\text { Night }\end{array}$ & $\begin{array}{l}\text { Many people feel concerned } \\
\text { Bankruptcy, rice is expensive }\end{array}$ & Uduk rice & $\begin{array}{l}\text { Begging for } \\
\text { safety }\end{array}$ \\
\hline Sapar & Day & Many people are doing exodus & $\begin{array}{l}\text { Uduk rice, } \\
\text { tulak chicken } \\
\text { side dish }\end{array}$ & Qunut prayer \\
\hline Rabingul Awal & $\begin{array}{l}\text { Day } \\
\text { Night }\end{array}$ & $\begin{array}{l}\text { Many people are persecuted } \\
\text { Many people are sick }\end{array}$ & $\begin{array}{l}\text { White rice, } \\
\text { white chicken } \\
\text { side dish }\end{array}$ & Bariklana prayer \\
\hline Rabingul Akhir & Day & $\begin{array}{l}\text { Lots of rain. All plants grow } \\
\text { well }\end{array}$ & $\begin{array}{l}\text { White } \\
\text { porridge, red } \\
\text { porridge }\end{array}$ & $\begin{array}{l}\text { Tolak bilahi } \\
\text { umur prayer }\end{array}$ \\
\hline Jumadil Awal & $\begin{array}{l}\text { Day } \\
\text { Night }\end{array}$ & $\begin{array}{l}\text { Many people pray diligently } \\
\text { Long drought, very hot } \\
\text { weather, many fruits are } \\
\text { damaged }\end{array}$ & $\begin{array}{l}\text { Five-colored } \\
\text { porridge }\end{array}$ & Selamat pina \\
\hline Jumadil Akhir & $\begin{array}{l}\text { Day } \\
\text { Night }\end{array}$ & - & $\begin{array}{l}\text { Red rice, } \\
\text { yellow chicken } \\
\text { side dish }\end{array}$ & $\begin{array}{l}\text { Begging for } \\
\text { safety }\end{array}$ \\
\hline Rejeb & $\begin{array}{l}\text { Day } \\
\text { Night }\end{array}$ & $\begin{array}{l}\text { Lots of disease outbreaks, lots } \\
\text { of sick animals } \\
\text { Many wars in the west }\end{array}$ & Black rice & Gospel Prayer \\
\hline Ruwah & $\begin{array}{l}\text { Day } \\
\text { Night }\end{array}$ & $\begin{array}{l}\text { Many people die, rice is } \\
\text { expensive } \\
\text { Rice is inexpensive }\end{array}$ & $\begin{array}{l}\text { Red rice, } \\
\text { chicken side } \\
\text { dish }\end{array}$ & Bariklana prayer \\
\hline Poso & $\begin{array}{l}\text { Day } \\
\text { Night }\end{array}$ & $\begin{array}{l}\text { Many people are starving, } \\
\text { people are concerned } \\
\text { Many people moved places }\end{array}$ & $\begin{array}{l}\text { Porridge, } \\
\text { dawet }\end{array}$ & Rasul prayer \\
\hline Syawal & $\begin{array}{l}\text { Day } \\
\text { Night }\end{array}$ & $\begin{array}{l}\text { Many people are sick } \\
\text { Many people go to war }\end{array}$ & Flour porridge & $\begin{array}{l}\text { Maskumambang } \\
\text { prayer }\end{array}$ \\
\hline Dulkangidah & $\begin{array}{l}\text { Day } \\
\text { Night }\end{array}$ & $\begin{array}{l}\text { Many priests } \\
\text { Many people move around }\end{array}$ & Liwet rice & Prayer on aging \\
\hline Besar & Night & $\begin{array}{l}\text { Many people die, many people } \\
\text { move around } \\
\text { The village experiences } \\
\text { prosperity, rice is inexpensive }\end{array}$ & $\begin{array}{l}\text { Ruwah, as well } \\
\text { as red, tulak, } \\
\text { lurik or } \\
\text { dorking, and } \\
\text { black chicken } \\
\text { side dishes } \\
\end{array}$ & Cemetry prayer \\
\hline
\end{tabular}

Overall, the discussion on earthquakes in this Serat Primbon was narrated with the divination structure consistently and with the same pattern. The pattern consists of the time of the earthquake, the meaning given, the slametan ceremony, and the form and content of the pray that was spoken. In summary, the all of it can be seen in Table 1. 
From the various meanings, a depiction is obtained that in addition to the context of the category of topics, the meaning is different ontologically in the values attached. In general, the values are divided into two parts. First, the meaning related to positive, good, and beneficial things for human life, such as rain begins to fall, plants begin to blossom, foods and clothing are affordable, abundant staple foods, such as rice, safety of the population, many people do good, and so on.

Second, the meanings given are things or events that are negative and not beneficial to human life. For example, there is a feud between citizens in the community, moral damage, people fighting for power, people doing exodus from their hometowns, disease outbreaks hit the community, many livestock die, long drought and drought engulfing the community.

The two models of meaning, in Serat Primbons, were not understood as the concept of God's commandment to inflict gifts, tests, or punishments to humans. The diversity of meanings given, containing either bad values or good values, was understood as part of the sunnah of God or Allah that exists in the life of the universe. All of that was accepted as a social, political, and cultural consequence in human life.

In Serat Primbon, earthquake events were not understood in the framework of the understanding of life tests, torments, or even God's punishment for humans due to human actions or various social events that occurred before the earthquake. By Javanese people, it was understood as an ordinary natural event which contains messages about events that will occur; and, as usually happening related to the awareness that lives in Javanese society, it was responded to by slametan ceremonies and prayer rituals. The prayers offered and the types of food served at the slametan ceremony vary. This diversity is related to the context of time when the earthquake occurred. For example, prayer for salvation; qunut prayer [nazilah] which contains a request for salvation of life, praying for God's guidance, avoiding slander and the determination in embracing Islam and faith; prayer to resist danger or tolak bilahi prayer to avoid doom and disaster; prayer for aging to ask for longevity and peace in life; turun sih prayer that is read when someone faces great difficulties because he or she is being tested by God; and the earth or bumi prayer to ask God for taking care the earth from damage and destruction, so that it becomes the path to the continuation of human life. The names of these prayers are related to the requests in the prayers (V 1847, 58).

As for matters relating to various foods served in the slametan ceremony are uduk rice, galang rice, red porridge, Galung rice, Tumpeng rice, Megana rice, Liwet rice, and Yellow rice (V 1847). The diversity of types of food served is a symbol in which the meanings were constructed as a medium in conveying various messages and attaching various requests to God (Compare to Giri, 2010).

\subsection{Human's efforts and hopes in god's power}

The various meanings constructed in the form of divinations, slametan events, and prayers offered to God are a series of meanings built by Javanese people in responding to and understanding earthquake events. These attitudes and understandings are a reflection of longstanding beliefs that are rooted in the life of Javanese people. First, theologically, the earthquake by the Javanese people is understood not as the curse of God to unbelievers or a test for believers. The perspective highlighted by the Javanese, as seen in the Serat Primbon, is 
awareness and caution for every event that occurs in the universe. Here, earthquakes were understood as natural events that are natural. It occurs due to natural factors (V 1847, 62). So, this natural event is not a form of curse or a test from God for humans. Because, every bad and or good consequence that arises due to natural events, is basicly determined by the perception and relationship of these events with human existence. Claims of an event as a bad thing are determined by the effects caused, which are not beneficial to human life. And vice versa, an event is seen as a good event because, in it, there are things that are beneficial to human life.

Second, earthquake events were understood as a field where awareness of the intimate relationship between humans and the universe must be strengthened. This conclusion was based on a cultural reality in which various traditions in Java are often associated with the existence of nature, such as giving alms to the earth or sedekah alam, giving alms to the sea or sedekah laut, and prayers that are offered directly with the theme of nature, such as praying for the earth or doa bumi. These diverse cultures were built as a means for everyone to preserve and care for nature as God's creation. People destroying the nature, in Javanese consciousness, have essentially corrupted God's creation, and such behavior is indirectly a form of insult to God. On the contrary, caring for nature means caring for God's creation, and this is a form of human love for God.

The holding of the slameten ceremonies and joint prayers performed by the Javanese people after the earthquake occurred is one way of aligning themselves with the natural cycle and for everything that happens in the universe. To maintain the balance and peace of life, the Javanese always align themselves with nature. Such attitudes and views also live in Balinese society with the concept of tri hita karana (tri means three, hita means happiness, and karana means cause). In this concept, happiness is created due to three causes, namely human relations, human relations with nature, and human relationships with God (Wardana \& Wisnu, 2013).

Self-alignment with nature, for the Javanese does not necessarily make themselves as passive and uncreative subjects, but efforts continue to be passed by everyone, and this is also part of something natural (sunnatullah). Mangkunegara IV in Wedhatama has confirmed that ngelmu iku kalakone kanti laku. This is an important teaching for Javanese in living their life and facing problems (Mangkunagara IV, 1989).

Third, besides maintaining harmony between humans, nature and God, Javanese also have an understanding that the existence of human beings in the universe cannot be separated from the Divine. The various kinds of prayers that were spoken after the earthquake were Javanese theological expressions of the existence of God as the source and nurse of life. In Javanese understanding, all living things will return to the God, as depicted in the concept of sangkan paraning dumadi. They believed that the perfection of life can be obtained when humans arrive at the innermost Reality, namely the God. This kind of awareness, in Serat Dewa Ruci, was depicted in the story of lelaku Bima who searched and found banyu suci perwitasari (the source of water of life) in order to achieve the perfection of life. Such awareness is parallel to the nature of life taught by Islam, that everything comes from God and will return to Him (innā lillāhi wa innā ilaihi rāji'ūn) (Widayoko, 1929). 
Slametan ceremonies and joint prayers conducted by the Javanese people after the earthquake were not only in the framework of maintaining harmony in life, both in the context of relations with fellow humans, God, and nature (Arinda, 2014), but also as an expression of gratitude to God for giving safety of life and, at the same time, as a hope and request that safety and harmony in the life of the universe can be obtained (Koentjaraningrat, 1984). Praying and giving alms as two main aspects of the ceremony ( $\mathrm{V}$ 1847, 58), from the theological perspective becomes one of the means in building disaster mitigation. To pray means to bind all living things in the world with the God, the Owner and Regulator of all living things. Such attitudes and understandings shape a person's mentality to be strong in facing and managing problems in all situations and conditions. In a broader context, the Javanese also have a belief that life is a loan from God. Living it is nothing more than an awareness of the process from one destiny to another, as written in God's decision and destiny. As for charity or alm giving, other than as an expression of gratitude, it is also an expression of the belief that lives in the Javanese inner space, in which giving and sharing are part of the ways to free oneself from all dangers and the path to conformity and harmony in life (Widayoko, 1929). Therein, the Javanese understood charity as a means to resist danger or tolak bilahi (V 1847, 62), an attitude which is part of the teachings of Islam (Giri, 2010).

Such attitudes and understandings of Javanese society are the way in which God's existence which is not reached by the mind is presented in everyone's consciousness. Through the creation of such symbols and rituals, a sense and awareness is created that God is always present and involved in every movement of nature and human life (Sholikin, 2010). That's where inner peace will be created.

Such attitudes and understandings of Javanese people over earthquake events is one of the strengths in building mental resilience. It became the basis for each individual in dealing with various bad things due to the earthquakes. Psychologically, such theological attitudes and understandings become a therapy for every individual in eliminating trauma and at the same time fostering awareness so that each individual is able to rise up and solve problems caused by the earthquake.

\section{Conclusion}

Earthquakes are understood by Javanese people as symbols in which they are constructed with various predictive meanings. These meanings relate to various aspects of human life and have negative and or positive nature for the life of the mankind. In addition, earthquake events were responded to by a ceremony in which prayers are offered and various alms are performed. All these activities were carried out as an effort to prevent disasters that can harm humans and the surrounding environment.

All of this reflects the Javanese theological interpretation in interacting with fellow beings based on positive thinking patterns, maintaining harmony in nature, and all events are understood as God's commands. Such a worldview, from a theological and psychological point of view, becomes a solid foundation in building attitudes of disaster mitigation and recovery from the trauma it causes.

\section{References}

Ardika, M., Meilano, I., \& Gunawan, E. (2015). Postseismic Deformation Parameters of the 2010 
M7.8 Mentawai, Indonesia, Earthquake Inferred from Continuous GPS Observations. Asian Journal of Earth Sciences, 8(4), 127-133. http://doi.org/10.3923/ajes.2015.127.133

Arinda, I. Y. (2014). Sedekah Bumi (Nyadran) Sebagai Konvensi Tradisi dan Islam Masyarakat Sraturejo Bojonegoro. El-Harakah, 16, 105-106.

Banerjee, P., Pollitz, F., Nagarajan, B., \& Bu, R. (2007). Coseismic Slip Distributions of the 26 December 2004 Sumatra - Andaman and 28 March 2005 Nias Earthquakes from GPS Static Offsets. Bulletin of Seismological Society of America, 97(1), 86-102. http://doi.org/10.1785/0120050609

Drewes, B. F., \& Mojau, J. (2006). Apa itu Teologi? Jakarta: BPK Gunung Mulia.

Elnashai, A. S., Kim, S. J., Yun, G. J., \& Sidarta, D. (2007). The Yogyakarta Earthquake of May 27, 2006.

Engdahl, E. R., Villasen, A., Deshon, H. R., \& Thurber, C. H. (2007). Teleseismic Relocation and Assessment of Seismicity (1918 - 2005) in the Region of the 2004 Mw 9.0 Sumatra Andaman and $2005 \mathrm{M} \mathrm{w} 8$. 6 Nias Island Great Earthquakes. Bulletin of the Seismological Society of America, 97(1), 43-61. http://doi.org/10.1785/0120050614

Ferguson, S. B., Wright, D. F., \& Packer, J. L. (1988). Theology. Downer Groves, Illionis: InterVarsity Press.

Giri, W. (2010). Sajen dan Ritual Orang Jawa. Yogyakarta: Penerbit Narasi.

Gusman, A. R., Tanioka, Y., Matsumoto, H., \& Iwasaki, S. (2009). Analysis of the Tsunami Generated by the Great 1977 Sumba Earthquake that Occurred in Indonesia. Bulletin of the Sismological Society of America, 99(4), 2169-2179. http://doi.org/10.1785/0120080324

Hayakawa, M., Itoh, T., Hattori, K., \& Yumoto, K. (2000). ULF electromagnetic precursors for an earthquake at Biak, Indonesia on February 17, 1996. Geohysical Research Letters, 27(10), 1531-1534.

Henry, C., \& Das, S. (2002). The Mw 8.2, 17 February 1996 Biak, Indonesia, earthquake: Rupture history, aftershocks, and fault plane properties. Journal of Geophysical Research, 107, 1-16. http://doi.org/10.1029/2001JB000796

Hermansyah. (2012). Naskah Ta'bir Gempa: Antara Mitigasi Bencana dan Kearifan Lokal di Aceh (Kajian Terhadap Naskah-Naskah Kuno). In Seminar Internasional Aceh Development Intenational Conference (ADIC) ke III 26-28 Maret 2012. Kuala Lumpur.

Hidayat, D., Barker, J. S., \& Satake, K. (1995). Modeling the Seismic Source and Tsunami Generation of the December 12, 1992 Flores Island, Indonesia, Earthquake. Pure and Applied Geophysics, 144(3/4), 537-554.

Indiyanto, A., \& Kuswanjono, A. (2012a). Agama, Budaya, dan Bencana, Kajian Integratif Ilmu, Agama, dan Budaya. Bandung: Mizan \& CRCS UGM.

Indiyanto, A., \& Kuswanjono, A. (2012b). Konstruksi Masyarakat Tangguh Bencana. Bandung: Mizan \& CRCS UGM. 
Indiyanto, A., \& Kuswanjono, A. (2012c). Respons Masyarakat Lokal atas Bencana, Kajian Integratif Ilmu, Agama, dan Budaya. Bandung: Mizan \& CRCS UGM.

Keefer, D. K. (2002). Investigating landslides caused by earthquakes - A historical review. Survey in Geophysics, 23, 473-510.

Kerle, N. (2010). International Journal of Applied Earth Observation and Geoinformation Satellite-based damage mapping following the 2006 Indonesia earthquake - How accurate was it ?, 12, 466-476. http://doi.org/10.1016/j.jag.2010.07.004

Koentjaraningrat. (1984). Kebudayaan Jawa. Jakarta: Balai Pustaka.

Latief, H., Puspito, N., \& Imamura, F. (2000). Tsunami Catalog and Zones in Indonesia. Journal of Natural Disaster Science, 22(1), 25-43. http://doi.org/10.2328/jnds.22.25

Lubis, N. (2007). Naskah, Teks, dan Metode Penelitian Filologi. Jakarta: Puslitbang Lektur Keagamaan.

Manga, M., Brumm, M., \& Rudolph, M. L. (2009). Earthquake triggering of mud volcanoes. Marine and Petroleum Geology, 26, 1785-1798. http://doi.org/10.1016/j.marpetgeo.2009.01.019

Mangkunagara IV. (1989). Serat Wedhatama. Dahara Prize.

Mannheim, K. (1949). Ideology and Utopia, an Introduction to the Sociology of Knowledge. Harcourt: Brace.

Mase, L. Z. (2019). The empirical analysis of soil liquefaction in Imogiri site, Yogyakarta, Indonesia. Potensi: Journal Sipil Politeknik, 21(1), 37-41. http://doi.org/10.35313/potensi.v21i1.1315

Mccloskey, J., Antonioli, A., Piatanesi, A., Sieh, K., Steacy, S., Nalbant, S., ... Dunlop, P. (2008). Tsunami threat in the Indian Ocean from a future megathrust earthquake west of Sumatra. Earth and Planetary Science Letters, 265(December 2004), 61-81. http://doi.org/10.1016/j.epsl.2007.09.034

Mccloskey, J., Lange, D., Tilmann, F., Nalbant, S. S., Bell, A. F., Natawidjaja, D. H., \& Rietbrock, A. (2010). The September 2009 Padang earthquake Darwin's geological time dilemma. Nature Geoscience, 3(2), 70-71. http://doi.org/10.1038/ngeo753

Nakamura, S. (1979). A Note on the Indonesian Earthquake and Tsunmi of 19 August 1977. Southeast Asian Studies, 17(1), 157-162.

Natawidjaja, D. H., Sieh, K., Chlieh, M., Galetzka, J., Suwargadi, B. W., Cheng, H., ... Ward, S. N. (2006). Source parameters of the great Sumatran megathrust earthquakes of 1797 and 1833 inferred from coral microatolls. Journal of Geophysical Research, 111, 1-37. http://doi.org/10.1029/2005JB004025

Okal, E. A., \& Reymond, D. (2003). The mechanism of great Banda Sea earthquake of 1 February 1938: applying the method of preliminary determination of focal mechanism to a historical event. Earth and Planetary Science Letters, 216, 1-15.

Paradise, T. R. (2005). Perception of earthquake risk in Agadir, Marocco: A Case Study from Muslim community. Enveronmental Hazards, 6, 167-180. 
Purbatjaraka, R. N. (1985). Ajaran Rahasia Sunan Bonang Suluk Wujil Jakarta. Jakarta: Depdikbud.

Ritzer, G. (2012). Teori Sosiologi: dari Sosiologi Klasik sampai Perkembangan Terakhir Postmodern, terjemahan. Yogyakarta: Pustaka Pelajar.

Ritzer, G., \& Goodman, D. J. (2004). Teori Sosiologi Modern, terj. Jakarta: Kencana.

Rosenzweig, C., Livermore, M., Jones, J. W., Curry, R. B., Boote, K. J., Allen, L. H., ... Fischer, G. (2006). Frictional Afterslip Following the 2005. Science, 312(June), 1921-1925.

Saatcioglu, M., Ghobarah, A., \& Nistor, I. (2006). Performance of Structures in Indonesia during the December 2004 Great Sumatra Earthquake and Indian Ocean. Earthquake Spectra, 22(S3), S295-S319. http://doi.org/10.1193/1.2209171

Satake, K., Putra, P. S., Gusman, A. R., Sunendar, H., Jujii, Y., Tanioka, Y., ... Yulianto, E. (2012). Tsunami Source of the 2010 Mentawai , Indonesia Earthquake Inferred from Tsunami Field Survey and Waveform Modeling Pure and Applied Geophysics Tsunami Source of the 2010 Mentawai , Indonesia Earthquake Inferred from Tsunami Field Survey and Waveform Mode. Pure Appplied Geophysics, 9-10, 1567-1582. http://doi.org/10.1007/s00024-0120536-y

Satyana, A. H. (2007). Bencana Geologi dalam "Sandhyâkâla" Jenggala dan Majapahit: Hipotesis Erupsi Gununglumpur Historis Berdasarkan Kitab Pararaton, Serat Kanda, Babad Tanah Jawi; Folklor Timun Mas; Analogi Erupsi LUSI; dan Analisis Geologi Depresi Kendeng-Delta Brantas. In Joint Convention Bali 2007 the 36th IAGI, The 32nd HAGI, and the 29th IATMI Annual Convention and Exhibition Bali, 13-16 November 2007. Bali.

Sholikin, M. (2010). Ritual dan Tradisi Jawa. Suka Buku.

Situmorang, R. ., Smit, R., \& Vessem, E. J. Van. (1992). Peta Geologi Lembar Jatirogo, Jawa. Jakarta: Pusat Penelitian dan Pengembangan Geologi.

Stein, S., \& Nunn, J. A. (1981). Analysis of split normal modes for the 1977 Indonesian earthquake. Bulletin of Seismological Society of America, 71(4), 1031-1047.

Tsuji, T., Yamamoto, K., Matsuoka, T., Yamada, Y., Onishi, K., Bahar, A., ... Abidin, H. Z. (2009). Earthquake fault of the 26 May 2006 Yogyakarta earthquake observed by SAR interferometry. Earth Planets Space, 61, 29-32.

Voight, B., Constantine, E. K., Siswowidjoyo, S., \& Torley, R. (2000). Historical eruptions of Merapi Volcano, Central Java, Indonesia, 1768 - 1998. Journal of Volcanology and Geothermal Research, 100, 69-138. http://doi.org/10.1016/S0377-0273(00)00134-7

Wang, D., Mori, J., \& Uchide, T. (2012). Supershear rupture on multiple faults for the Mw 8.6 Off Northern Sumatra, Indonesia earthquake of April 11, 2012. Geophysical Research Letters, 39(August 2015), 4-9. http://doi.org/10.1029/2012GL053622

Wardana, J. H., \& Wisnu. (2013). Tri Hita Karana, the Spirit of Bali. Jakarta: Kepustakaan Populer Gramedia. 
Widayoko, E. (1929). Dewa Roetji. Kediri: Tan Koen Swie.

Yamada, M., Wang, G., \& Mukai, K. (2013). The Classification and Features of Earthquake-Induced Landslides in the World. In K. U. et Al. (Ed.), Earthquake-Induced Landslides (pp. 117-124). Berlin Heidelberg: Springer-Verlag. http://doi.org/10.1007/978-3-642-32238-9

Zhou, Y. H., Xu, L. S., \& Chen, Y. T. (2002). Source Process of the 4 June 2000 Southern Sumatra, Indonesia, Earthquake. Bulletin of Seismological Society of America, 92(5), 2027-2035. 